\title{
Interferon- $\gamma$ acts as a regulator in the trade-off between phagocytosis and production performance in dwarf chickens
}

\author{
Yitong Yuan', Shunqi Liu², Yue Zhao ${ }^{2}$, Ling Lian ${ }^{1 *}$ and Zhengxing Lian ${ }^{1 *}$ (D)
}

\begin{abstract}
Background: Interferon- $\gamma$ (IFN- $\gamma)$ is critical for innate and adaptive immunity against viral and bacterial infections. IFN- $\gamma$ reportedly affects the phagocytic ability of monocytes and macrophages as well as regulates pituitary function in humans and mice. The present study analyzed the impact of IFN- $\gamma$ on monocyte and macrophage phagocytosis, production performance, and pituitary function in vivo and in vitro (in dwarf chickens). IFN- $\gamma$ was injected into dwarf chickens through a vein, and then, the laying rate, average egg weight, and levels of follicle-stimulating hormone (FSH) and IFN- $\gamma$ were measured in treatment and control groups. For the in vitro experiment, the pituitary tissues were supplemented with IFN- $\gamma$, and the mRNA expression levels of follicle-stimulating hormone beta subunit (FSH- $\beta$ ), interferon gamma receptor 1 (IFNGR1), and interferon gamma receptor 2 (IFNGR2) in the pituitary were assessed.

Results: Monocyte and macrophage phagocytosis product (PP) was decreased by IFN- $\gamma$ treatment in a dose-dependent manner in vitro. In the in vivo experiment, the level of IFN- $\gamma$ in the treatment group was higher than that in the control group at $7 \mathrm{~d}(P<0.05), 14 \mathrm{~d}(P<0.01)$, and $21 \mathrm{~d}(P<0.01)$ post-injection. Compared with the control group, monocyte and macrophage PP was lower in the treatment group after injection $(P<0.01)$. The laying rate was higher in the treatment group than in the control group at 2 and 3 wk post-injection $(P<0.05)$. There was a significant difference between the treatment and control groups in the levels of FSH at $1,3,7$, and $14 \mathrm{~d}$ post-injection $(P<0.01)$. In the in vitro experiment, increased mRNA expression levels of FSH- $\beta$, IFNGR1, and IFNGR2 were observed in the treatment group after stimulation with $100 \mathrm{U} / \mathrm{mL}$ IFN- $\gamma$ for $24 \mathrm{~h}$ compared to those in the control group $(P<0.05)$.

Conclusions: IFN- $\gamma$ inhibited the phagocytosis of monocytes and macrophages; up-regulated the mRNA expression levels of the FSH- $\beta$, IFNGR1, and IFNGR2; enhanced the secretion of FSH; and improved the laying rate. IFN- $\gamma$ might be an important regulator in the trade-off between the immune effect and production performance in dwarf chickens.
\end{abstract}

Keywords: Dwarf chicken, Interferon- $\gamma$, Macrophage, Monocyte, Phagocytosis product, Production performance

\footnotetext{
*Correspondence: lianlinglara@126.com; lianzhxcau@126.com

${ }^{1}$ Key Laboratory of Animal Genetics and Breeding of the Ministry of

Agriculture, Beijing Key Laboratory for Animal Genetic Improvement,

Department of Animal Genetics and Breeding, College of Animal Science

and Technology, China Agricultural University, Beijing 100193, China

Full list of author information is available at the end of the article
}

(c) The Author(s). 2018 Open Access This article is distributed under the terms of the Creative Commons Attribution 4.0 International License (http://creativecommons.org/licenses/by/4.0/), which permits unrestricted use, distribution, and reproduction in any medium, provided you give appropriate credit to the original author(s) and the source, provide a link to the Creative Commons license, and indicate if changes were made. The Creative Commons Public Domain Dedication waiver (http://creativecommons.org/publicdomain/zero/1.0/) applies to the data made available in this article, unless otherwise stated. 


\section{Background}

Production performance has a profound and lasting significance for poultry in terms of both evolutionary and economic perspectives $[1,2]$. In commercial settings, improvements in production traits are always more profitable, but they also put the birds at increased risk of stress and disease because of unbalanced resource allocation [3]. Selection for high production efficiency in broilers can have a detrimental impact on physiological and immunological function, such as higher mortality and susceptibility to disease [4, 5]. For example, infections caused by various pathogens were observed in turkeys artificially selected for high egg production [6]. Other researchers showed that White Leghorn chickens with low antibodies to sheep red blood cells showed increased egg production after artificial selection for 24 generations [3]. Our previous study indicated that dwarf chickens with low levels of monocyte and macrophage phagocytosis exhibited low antibody titers to avian influenza H9 but greater laying rates during the early laying period (unpublished observations). Therefore, stronger production performance is typically accompanied by weaker immune responses. Thus, the trade-off between the immune effect and production performance remains to be clarified.

Interferon- $\gamma$ (IFN- $\gamma)$, the only member of the type II IFNs, is a pro-inflammatory cytokine mainly produced by $\mathrm{T}$ helper type 1 cells, CD8+ cytotoxic lymphocytes, natural killer cells, B cells, natural killer T cells, and professional antigen-presenting cells $[7,8]$. IFN- $\gamma$ plays a vital role in innate and adaptive immunity that activates the host defense against viral and bacterial infection [810]. IFN- $\gamma$ exerts its immunological function by activating various host cells, especially monocytes and macrophages, and also can regulate the expression of the class II major histocompatibility complex [11]. As professional phagocytic cells, monocytes and macrophages are indispensable in the host defense mechanism, enhancing the immune response by releasing pro-inflammatory and inflammatory cytokines $[9,12,13]$. IFN- $\gamma$ has an inhibitory effect on the nonopsonized phagocytosis of macrophages in mice and humans. Monocyte- and macrophagemediated microbial phagocytosis was shown to be decreased by IFN- $\gamma$ in viral infections in mice $[14,15]$. Peritoneal macrophages from mice treated with recombinant mouse IFN- $\gamma$ exhibited reduced phagocytosis of chicken red blood cells and Escherichia coli [16]. In humans, this inhibition was also found in the phagocytic process of monocyte-derived macrophages [17, 18]. However, few studies have been conducted on the effect of IFN- $\gamma$ on phagocytic activity in chickens.

Previous studies have reported that IFN- $\gamma$ can also regulate pituitary function by influencing hormone secretion. For example, inhibitory effects of IFN- $\gamma$ on adrenocorticotropic hormone, prolactin, and growth hormone were observed in anterior pituitary cells from 3month-old female Wistar rats [10]. In another study, exogenous IFN- $\gamma$ increased the expression of growth hormone in rat anterior pituitary cells in a dose-dependent manner [19]. Furthermore, subcutaneous IFN- $\gamma$ injections in humans led to increased cortisol levels [20]. These findings demonstrated that IFN- $\gamma$ may mediate the production of pituitary hormone. However, in dwarf chickens, the effect of IFN- $\gamma$ on the secretion of pituitary hormone has not been studied yet.

The immune effect and production performance are both essential aspects during long-term breeding, and a negative relationship between them has been found; however, how to maintain this balance have not been resolved. Here, we hypothesized that IFN- $\gamma$ maintains or converts the allocation of resources between production and immune function. Accordingly, the objective of the present investigation was to clarify the effect of IFN- $\gamma$ on monocyte and macrophage phagocytosis, pituitary function, and performance in dwarf chickens. This study will provide novel insights into the impact of IFN- $\gamma$ on both immune function and production traits. IFN- $\gamma$ can potentially be utilized in chicken breeding as a regulator of this balance.

\section{Methods}

\section{Experimental animals}

All animal procedures were approved by the Experimental Animal Care and Use Committee at China Agricultural University (Beijing, China), and the experiments were performed according to regulations and guidelines established by this committee. One flock of 160 dwarf hens and another flock of 786 dwarf hens at 12 wk of age were obtained from the Genetic Resource Center of China Agricultural University (Beijing, China). All chickens were fed ad libitum and reared under standard management and environmental conditions.

\section{Isolation and culture of chicken monocytes and macrophages}

One milliliter of peripheral blood was collected in heparin $(15 \mathrm{U} / \mathrm{mL})$ (China National Pharmaceutical Group Corporation, Beijing, China) from the brachial wing veins of 160 dwarf hens at 12 wk of age. Peripheral blood mononuclear cells (PBMCs) were isolated using Ficoll-Paque (Sigma, St. Louis, MO, USA) gradient centrifugation as previously described [21, 22]. Isolated cells were washed twice in $1 \mathrm{~mL}$ of phosphate buffered saline (PBS, Hyclone, Logan, UT, USA) by centrifugation at $800 \times g$ for $10 \mathrm{~min}$. Trypan blue solution (Sigma) was used to assess the PBMC number and viability. PBMCs were resuspended in RPMI 1640 medium (Gibco, 
Invitrogen, La Jolla, CA, USA) supplemented with 10\% fetal bovine serum (Gibco, Invitrogen) and $1 \%$ penicillinstreptomycin (Gibco, Invitrogen). Afterward, $1 \times 10^{6}$ cells/well were seeded in 96-well plates (Corning, Inc., Corning, NY, USA) (6 wells per sample) and incubated at $37{ }^{\circ} \mathrm{C}$ with $5 \% \mathrm{CO}_{2}$. Non-adherentcells (lymphocytes) were removed $24 \mathrm{~h}$ and $48 \mathrm{~h}$ after incubation, and approximately $90 \%$ of the adherent cells were monocytes and macrophages [21,23].

\section{Preparation of dyed-tumor cells using thiazolyl blue tetrazolium bromide (MTT)}

Human intestinal epithelial adenocarcinoma cells (Peking Union Medical College Hospital, Beijing, China, HCT-8) $\left(1 \times 10^{5}\right.$ cells $\left./ \mathrm{mL}\right)$ were cultured in $100-\mathrm{mm}$ culture plates (Corning) containing RPMI 1640 medium (Gibco, Invitrogen) supplemented with $10 \%$ fetal bovine serum (Gibco, Invitrogen) and $1 \%$ penicillin-streptomycin (Gibco, Invitrogen) at $37{ }^{\circ} \mathrm{C}$ with $5 \% \mathrm{CO}_{2}$. When the cells reached 70 to $80 \%$ confluence $\left(1 \times 10^{7}\right.$ cells per plate), MTT (Amresco, Radnor, PA, USA) solution $(5 \mathrm{mg} / \mathrm{mL}$ ) was added to the plate, and the cells were dyed for $10 \mathrm{~h}$. The cells were washed three times with PBS (Hyclone). The cell suspension was collected in a sterile tube and then stored at $4{ }^{\circ} \mathrm{C}$. The dyed HCT- 8 cells were used as phagocytic antigens as previously described [24].

\section{Monocyte and macrophage phagocytosis product assay}

The detection method of monocyte and macrophage phagocytosis was according to previous publications [24]. After $72 \mathrm{~h}$ of culture, the density of monocytes and macrophages was approximately $2 \times 10^{4}$ cells/well. In the treatment wells (three wells), dyed HCT-8 cells $\left(1 \times 10^{6}\right.$ cells) were added to the monocytes and macrophages in each well followed by incubation for $10 \mathrm{~h}$. In the control wells (three wells), MTT (Amresco) solution $(5 \mathrm{mg} / \mathrm{mL}$ ) was added to the monocytes and macrophages followed by incubation for $4 \mathrm{~h}$. Then, the cells were washed three times with PBS (Hyclone), and $150 \mu \mathrm{L}$ of dimethyl sulfoxide (Sigma) was added. The experiments were performed in triplicate. The absorbance of each well was detected at $575 \mathrm{~nm}$ and $630 \mathrm{~nm}$ (blank wells) with a Microplate Reader (BioTek, Winooski, VT, USA). Phagocytosis product (PP) was used as an indicator of the phagocytic ability of monocytes and macrophages and was calculated as follows: $\mathrm{PP}=$ absorbance (treatment wells) / absorbance (control wells).

\section{Detection of monocyte and macrophage PP after IFN- $\gamma$ stimulation in vitro}

Eight chickens with higher PP levels were selected from among $160 \mathrm{dwarf}$ hens. Peripheral blood $(3 \mathrm{~mL})$ was collected from the wing veins of each chicken at $12 \mathrm{wk}$ of age. PBMCs were isolated by Ficoll-Hypaque density gradient centrifugation. After $24 \mathrm{~h}$ of culture, monocytes and macrophages were washed three times with PBS (Hyclone), and non-adherent cells (mostly lymphocytes) were removed. The density of monocytes and macrophages was approximately $2 \times 10^{4}$ cells/well. Recombinant chicken IFN- $\gamma$ (Shanghai Medicine'nest Pharmaceutical Co. Ltd., Shanghai, Beijing) was prepared at different concentrations in PBS (Hyclone). In the treatment wells, monocytes and macrophages were incubated with IFN- $\gamma$ at concentrations of $0 \mathrm{ng} / \mathrm{mL}, 1 \mathrm{ng} / \mathrm{mL}$, $3 \mathrm{ng} / \mathrm{mL}, 30 \mathrm{ng} / \mathrm{mL}, 300 \mathrm{ng} / \mathrm{mL}$, and $1,000 \mathrm{ng} / \mathrm{mL}$ per sample. The medium was changed after $48 \mathrm{~h}$ of treatment. Dyed HCT-8 cells were added to monocytes and macrophages in the treatment wells, and MTT (Amresco) solution $(5 \mathrm{mg} / \mathrm{mL}$ ) was added to monocytes and macrophages in the control wells. PP was evaluated as described earlier.

\section{Determination of serum IFN- $\gamma$ in chickens after IFN- $\gamma$ injection in vivo}

Sixty dwarf chickens with higher PP levels and similar body weights were selected from among $160 \mathrm{dwarf}$ hens at 23 wk of age. The chickens were randomly divided into treatment and control groups. The chickens in the treatment group were intravenously injected with recombinant chicken IFN- $\gamma(14,000 \mathrm{U} / \mathrm{kg})$ (Shanghai Medicine'nest Pharmaceutical Co. Ltd) for 7 consecutive days. Chickens in the control group were simultaneously intravenously injected with $1 \mathrm{~mL}$ of PBS (Hyclone). The serum IFN- $\gamma$ levels in the treatment and control groups were determined using a commercial chicken specific ELISA kit (Elabscience Biotechnology Co., Ltd., Wuhan, Hubei, China) at $0,1,3,7,14,21$, and $28 \mathrm{~d}$ postinjection.

\section{Detection of monocyte and macrophage PP after IFN- $\nu$ injection in vivo}

At $0,1,3,7,10,14,21,28$, and $35 \mathrm{~d}$ post-injection, peripheral blood was collected from the wing veins, and PBMCs were isolated. After $72 \mathrm{~h}$ of culture, the PP of monocyte and macrophage was evaluated as described earlier.

\section{Measurement of production performance after IFN- $\gamma$ injection in vivo}

The egg production of the treatment and control groups was recorded, and all the eggs laid by each hen were weighed successively for $7 \mathrm{wk}$ after injection with IFN- $\gamma$. The individual laying rate was calculated as the total number of laying eggs divided by the total number of chickens and multiplied by $100 \%$. Average egg weight was calculated the total weight of laying eggs divided by the total number of eggs collected and multiplied by $100 \%$. 
The serum follicle-stimulating hormone (FSH) levels of chickens in the treatment and control groups was detected using a radioimmunoassay kit (Beijing North Institute of Biological Technology, Beijing, China) at $0,1,3,7,14,21$ and $28 \mathrm{~d}$ post-injection. The experiments were performed in triplicate.

\section{Pituitary gland stimulated by chicken IFN- $\gamma$ in vitro and FSH concentration measurement}

The monocyte and macrophage PP levels of 786 dwarf hens were detected at $12 \mathrm{wk}$ of age as described earlier. Forty dwarf hens with higher PP levels were selected at 25 wk of age and euthanized. The pituitary was immediately removed and weighed. The pituitary was washed twice with PBS (Hyclone) and finely sliced. The pituitary tissues were placed in 24-well plates (Corning) containing $500 \mu \mathrm{L}$ of serum-free RPMI 1640 medium (Gibco, Invitrogen) supplemented with $1 \%$ penicillinstreptomycin (Gibco, Invitrogen) and pre-incubated for $1 \mathrm{~h}$ with unceasing shaking followed by manual dispersion under $37{ }^{\circ} \mathrm{C}$ and $5 \% \mathrm{CO}_{2}$. One hour later, the medium was changed. The pituitary tissues were cultured for $24 \mathrm{~h}$ or $48 \mathrm{~h}$ without cytokines or with different concentrations of IFN- $\gamma(100,500$, and 1,000 U/mL) in serum-free RPMI 1640 medium (Gibco, Invitrogen). After incubation, the supernatants and the pituitary tissues were separately collected and stored at $-80{ }^{\circ} \mathrm{C}$ for subsequent assay. The concentrations of FSH in culture supernatants were measured with the commercial radioimmunoassay kits (Beijing North Institute of Biological Technology, Beijing, China).

\section{RNA extraction and real-time PCR}

Total RNA was extracted with TRIzol Reagent (Invitrogen, Gibco-BRL, Bethesda, MD, USA). The yield of RNA was determined using a spectrophotometer (DS-11, DeNovix, Inc., Wilmington, DE, USA), and the integrity was evaluated by RNA electrophoresis. Total RNA was reverse transcribed into cDNA using a QuantScript
Reverse Transcription Kit (Takara Bio, Dalian, China) in a total volume of $10 \mu \mathrm{L}$ containing $0.5 \mu \mathrm{g}$ RNA, $0.5 \mu \mathrm{L}$ PrimerScript RT Enzyme Mix I, $0.5 \mu \mathrm{L}$ RT Primer Mix, and $2 \mu \mathrm{L}$ Primer Script Buffer, followed by incubation at $37{ }^{\circ} \mathrm{C}$ for $15 \mathrm{~min}$ and $85^{\circ} \mathrm{C}$ for $5 \mathrm{~s}$.

The specific sequences of the primers were designed and synthesized by Sangon Biotech Co., Ltd. (Shanghai, China) and are shown in Table 1. Real-time PCR was performed using a real-time QPCR System (Mx3000P, Agilent technologies, Santa Clara, CA, USA) with a $20-\mu \mathrm{L}$ reaction mixture including $1 \mu \mathrm{L}$ cDNA, $0.4 \mu \mathrm{mol} / \mathrm{L}$ of forward and reverse primer, $0.4 \mu \mathrm{L}$ ROX reference dye, and $10 \mu \mathrm{L}$ SYBR Premix Ex Taq II (Takara Bio). The amplification conditions were as follows: $95{ }^{\circ} \mathrm{C}$ for $30 \mathrm{~s}$ and 40 cycles of $95{ }^{\circ} \mathrm{C}$ for $5 \mathrm{~s}, 60{ }^{\circ} \mathrm{C}$ for $30 \mathrm{~s}, 95{ }^{\circ} \mathrm{C}$ for $15 \mathrm{~s}, 60^{\circ} \mathrm{C}$ for $1 \mathrm{~min}$, and $95^{\circ} \mathrm{C}$ for $15 \mathrm{~s}$. Each sample was run in triplicate. The mRNA expression level of target genes was calculated using the $2^{-\Delta \Delta C t}$ method as previously described [25].

\section{Statistical analysis}

The difference between two means was evaluated using Student's $t$-test. Data are presented as the mean \pm standard error (SE). Statistical analyses were performed using SPSS17.0 software (IBM Co. Ltd., Armonk, NY, USA). Differences were considered statistically significant at $P<0.05$ and highly significant at $P<0.01$.

\section{Results}

The effect of IFN- $\gamma$ on monocyte and macrophage PP in vitro

The results showed that monocyte and macrophage PP decreased in a dose-dependent manner after stimulation with chicken IFN- $\gamma$ for $48 \mathrm{~h}$ (Fig. 1). The difference was significant at concentrations of $3 \mathrm{ng} / \mathrm{mL} \quad(P<0.05)$, $30 \mathrm{ng} / \mathrm{mL}(P<0.05), 300 \mathrm{ng} / \mathrm{mL}(P<0.01)$, and $1,000 \mathrm{ng} / \mathrm{mL}$ $(P<0.01)$.

Table 1 Real-time PCR primers sequences for the target genes

\begin{tabular}{|c|c|c|c|c|}
\hline Gene $^{a}$ & Accession No. & Primer Sequences ${ }^{\mathrm{b}}\left(5^{\prime} \rightarrow 3^{\prime}\right)$ & Product size, bp & Temperature, ${ }^{\circ} \mathrm{C}$ \\
\hline \multirow[t]{2}{*}{ GAPDH } & NM_204305.1 & F: CTGAGAACGGGAAACTTGTG & 105 & 60 \\
\hline & & R: CCACAACATACTCAGCACCTG & & \\
\hline \multirow[t]{2}{*}{$F S H-\beta$} & NM_204257.1 & F: AGCAGTGGAAAGAGAAGAATGTGA & 151 & 60 \\
\hline & & R: TGTTTCATACACAACCTCCTTGAAG & & \\
\hline \multirow[t]{2}{*}{ IFNGR1 } & NM_001130387.1 & F: AACCTGAGCATCCCAGTTCC & 135 & 60 \\
\hline & & R: ACTCCAAGCCTGCGTGATAG & & \\
\hline \multirow[t]{2}{*}{ IFNGR2 } & NM_001008676.2 & F: GCACCGGAGGATGTAATGGT & 145 & 60 \\
\hline & & R: GGGTGCAGTCCATCTCACTC & & \\
\hline
\end{tabular}

${ }^{\mathrm{a}} \mathrm{GAPDH}$ glyceraldehyde-3-phosphate dehydrogenase, FSH- $\beta$ follicle stimulating hormone beta subunit, IFNGR1 interferon gamma receptor 1 , IFNGR2 interferon gamma receptor 2

${ }^{b} F$, forward; $R$, reverse 


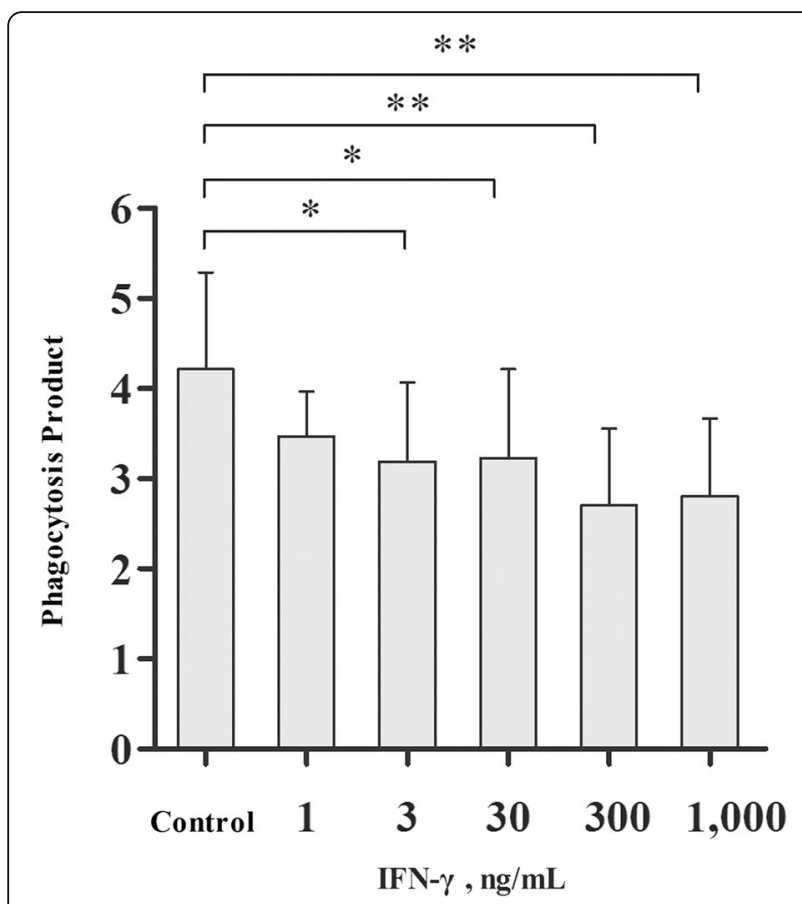

Fig. 1 Monocyte and macrophage phagocytosis product (PP) after interferon- $\gamma(\mathrm{IFN}-\gamma)$ stimulation for $48 \mathrm{~h}$ in vitro $(n=8)$. Bars represent the mean \pm standard error $(\mathrm{SE}) .{ }^{*}$ indicates $P<0.05$, ** indicates $P<0.01$

The level of serum IFN- $\gamma$ in dwarf chicken after IFN- $\gamma$ injection in vivo

After injection with exogenous IFN- $\gamma$, the serum IFN- $\gamma$ level in chickens increased gradually in the treatment group (Fig. 2). The difference was significant at $7 \mathrm{~d}(P<0.05), 14 \mathrm{~d}$ $(P<0.01)$, and $21 \mathrm{~d}(P<0.01)$ post-injection.

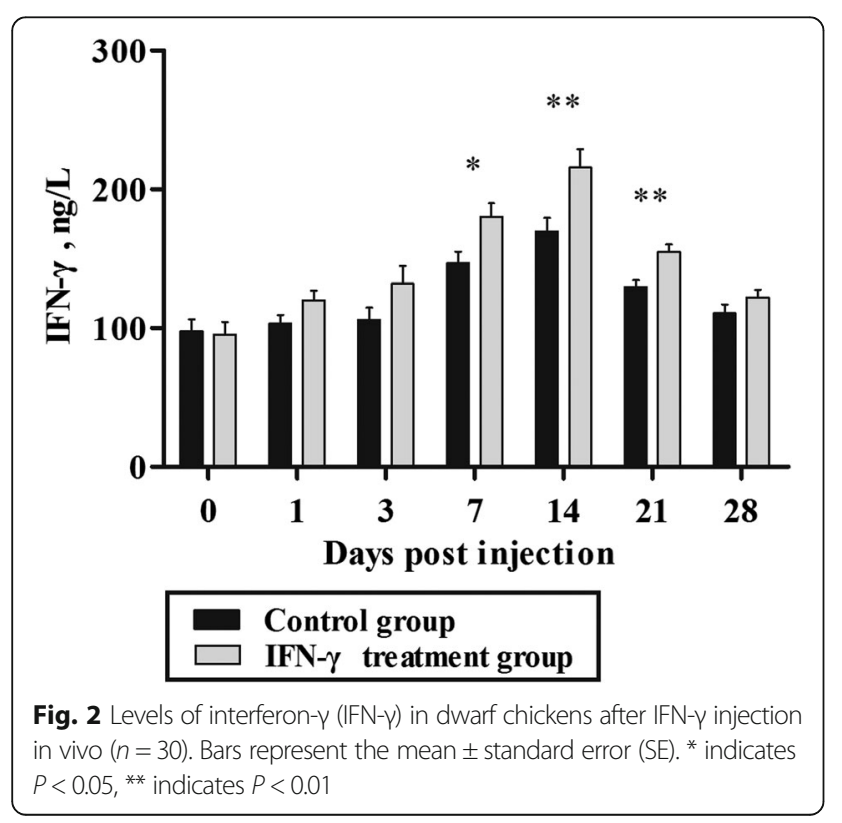

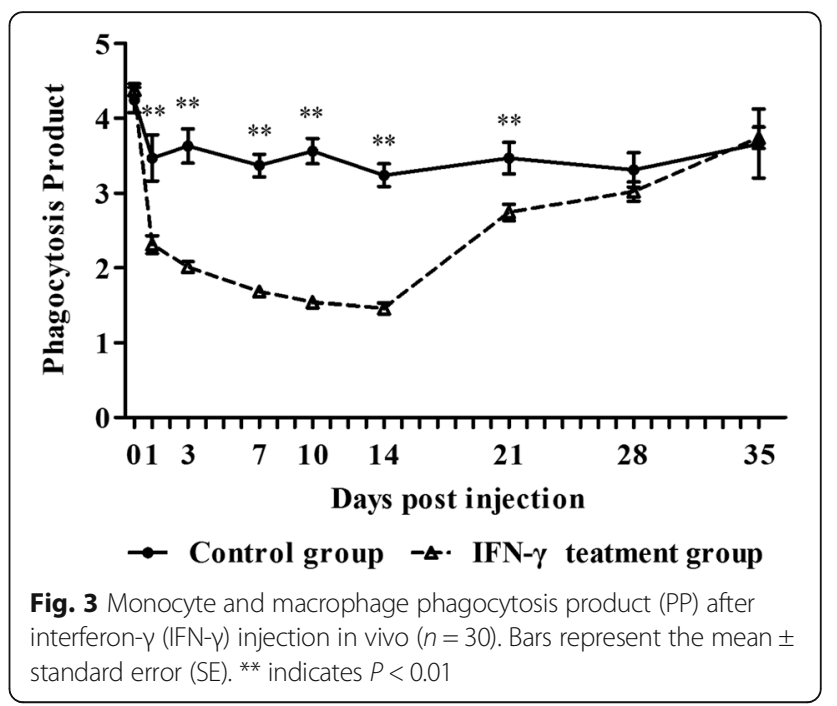

The effect of IFN- $\gamma$ on monocyte and macrophage PP in vivo

Monocyte and macrophage PP in the treatment group decreased gradually after IFN- $\gamma$ injection, with the lowest value at $14 \mathrm{~d}$ post-injection (Fig. 3). The PP was lower in the treatment group than in the control group at $1,3,7,10,14,21$, and $28 \mathrm{~d}$ post-injection, and these differences were significant at $1,3,7,10,14$, and $21 \mathrm{~d}$ post-injection $(P<0.01)$.

The production performance of dwarf chickens after IFN- $\nu$ injection in vivo

The laying rate of chickens in the treatment group was higher than that in the control group during the period from 1 to 7 wk post-injection (Fig. 4). The difference

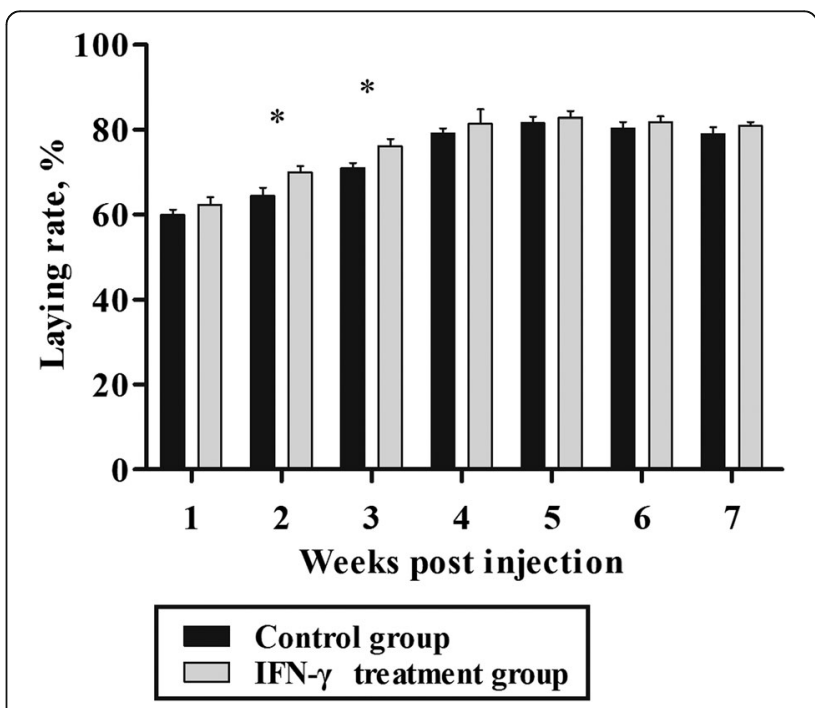

Fig. 4 Laying rate of dwarf chickens after interferon- $\gamma($ IFN- $\gamma)$ injection in vivo $(n=30)$. Bars represent the mean \pm standard error (SE). * indicates $P<0.05$ 
was significant at 2 and 3 wk post-injection $(P<0.05)$. The difference in the average egg weight of chickens between the treatment and control groups was not significant at each week $(P>0.05)$ (Fig. 5).

The levels of serum FSH increased after injection with IFN- $\gamma$ (Fig. 6). There was a significant difference between the treatment and control groups at 1, 3, 7, and $14 \mathrm{~d}$ post-injection $(P<0.01)$.

\section{Concentrations of FSH in culture supernatants of the pituitary after IFN- $\gamma$ stimulation in vitro}

To determine the mechanism underlying this production-promoting function, the FSH levels in culture supernatants of the pituitary after IFN- $\gamma$ stimulation was investigated. As shown in Fig. 7, when the pituitary were treated with 100 and $500 \mathrm{U} / \mathrm{mL} \mathrm{IFN- \gamma}$ for $24 \mathrm{~h}$, a significant effect on FSH release was observed in the treatment group relative to the control group $(P<0.05)$. The concentrations of FSH did not differ significantly between the treatment and control groups after stimulation for $48 \mathrm{~h}(P>0.05)$.

\section{Gene expression in the pituitary after IFN- $-\gamma$ stimulation in} vitro

The effect of IFN- $\gamma$ on the follicle-stimulating hormone beta subunit $(F S H-\beta)$ mRNA expression level in the pituitary is shown in Fig. 8a. Compared with the control group, IFN- $\gamma$ unregulated $F S H-\beta$ mRNA expression in the pituitary at a concentration of $100 \mathrm{U} / \mathrm{mL}$ after stimulation for $24 \mathrm{~h}(P<0.05)$. No noticeable difference was detected between the treatment and control groups after stimulation for $48 \mathrm{~h}(P>0.05)$.

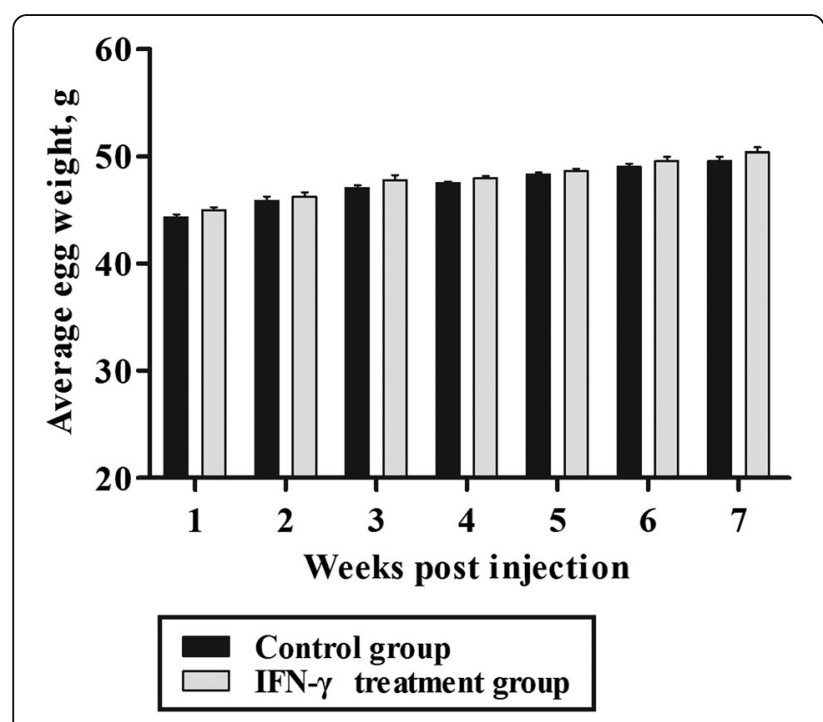

Fig. 5 Average egg weight of dwarf chickens after interferon- $\gamma$ (IFN- $\gamma$ ) injection in vivo $(n=30)$. Bars represents the mean \pm standard error (SE)

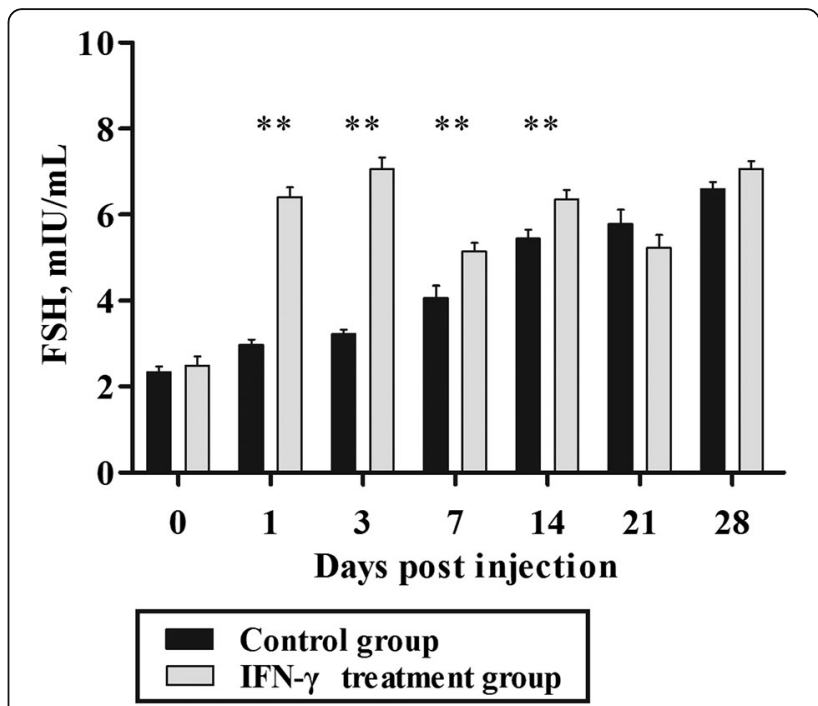

Fig. 6 Levels of follicle-stimulating hormone (FSH) in dwarf chickens after interferon- $\gamma($ IFN- $\gamma)$ injection in vivo $(n=30)$. Bars represent the mean \pm standard error (SE). ${ }^{* *}$ indicates $P<0.01$

In contrast to $F S H-\beta$ expression, the mRNA expression levels of interferon gamma receptor 1 (IFNGR1) and interferon gamma receptor 2 (IFNGR2) in the pituitary cultured with $100 \mathrm{U} / \mathrm{mL}$ IFN- $\gamma$ for $24 \mathrm{~h}$ significantly increased compared with those in the control group $(P<0.05)$ (Fig. $8 \mathrm{~b}$ and $\mathrm{c})$. However, no significant change was observed after treatment for $48 \mathrm{~h}(P>0.05)$.

\section{Discussion}

In the egg production industry, higher egg yield should not be blindly emphasized. Overabundant resources allocated to production performance may result in the impairment of other functions, especially the immune response. Thus, more attention should be paid to the

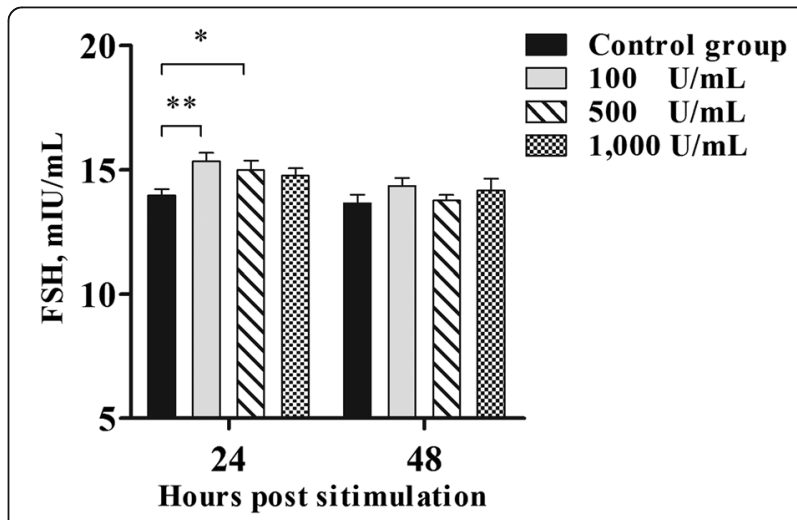

Fig. 7 Concentrations of FSH in culture supernatants of the pituitary after IFN- $\gamma$ stimulation in vitro ( $n=10$, per group). Bars represent the mean \pm standard error (SE). * indicates $P<0.05,{ }^{*}$ indicates $P<0.01$ 

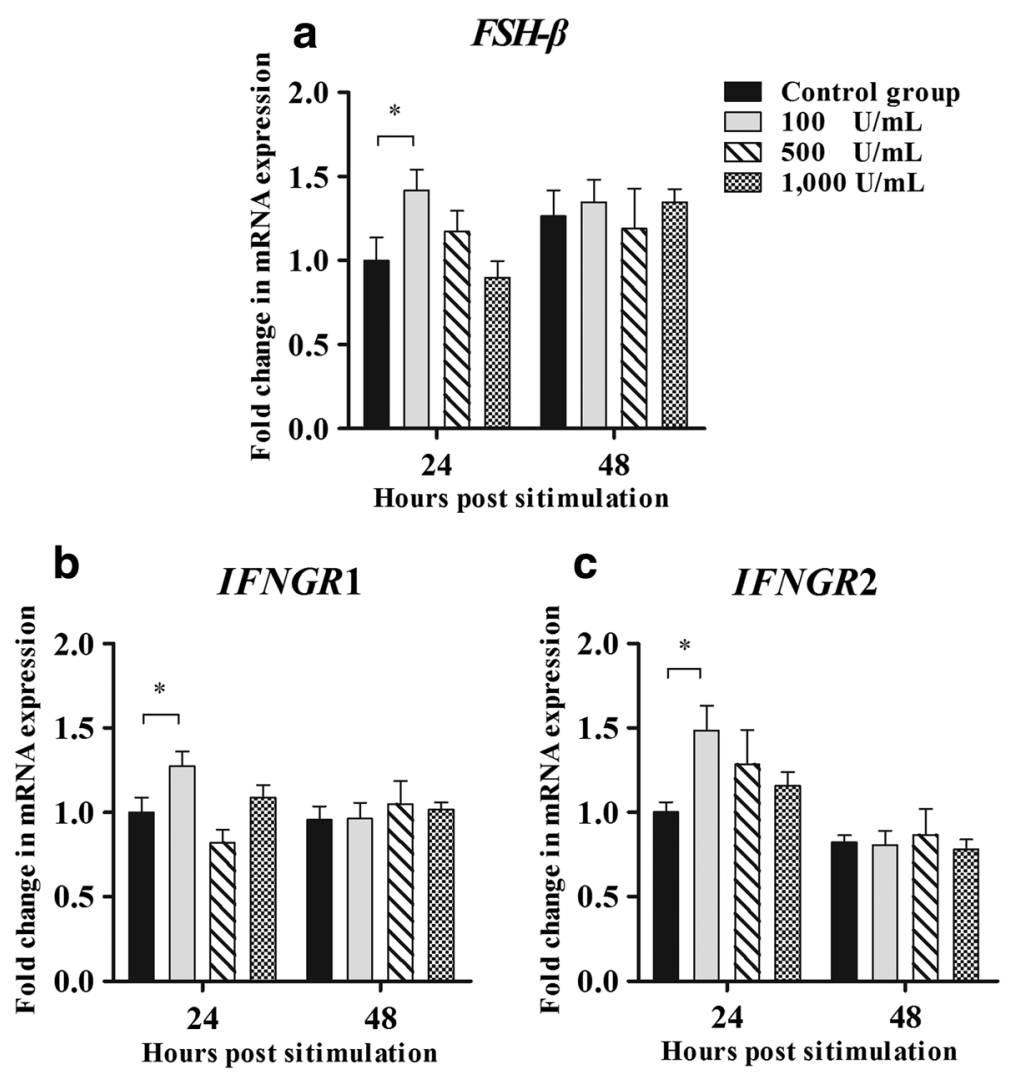

Fig. 8 Gene expression in the pituitary after interferon- $\gamma$ (IFN- $\gamma)$ stimulation in vitro ( $n=10$, per group). a The mRNA expression of follicle-stimulating hormone- $\beta$ (FSH- $\beta$ ). b The mRNA expression of interferon gamma receptor 1 (IFNGR1). $\mathbf{c}$ The mRNA expression of interferon gamma receptor 2 (IFNGR2). Bars represent the mean \pm standard error (SE). * indicates $P<0.05$

balance between greater production performance and an effective immune function.

The present study demonstrated that IFN- $\gamma$ has an inhibitory effect on the phagocytosis of monocytes and macrophages in a dose-dependent manner in vitro. In the in vivo experiment, the inhibition of PP was immediate at $1 \mathrm{~d}$ post-injection. The maximum inhibiting effect on PP appeared at $14 \mathrm{~d}$ and persisted until $28 \mathrm{~d}$ postinjection. Our results are consistent with a study reporting that the phagocytic percentage of mouse peritoneal macrophages to chicken erythrocytes decreased by more than one-half and that the phagocytic percentage of $E$. coli decreased by one-third after treatment with IFN- $\gamma$ [16]. In addition, the ability of human PBMCs to phagocytize sheep red blood cells was reported to significantly decrease after being cultured for $48 \mathrm{~h}$ with IFN- $\gamma$ at different concentrations, which is in agreement with our results $[17,26]$. IFN $-\gamma$ has a dual effect on monocyte and macrophage function that enhances the respiratory burst via up-regulating the class II major histocompatibility complex and suppresses the capacity of nonopsonic receptors on the surface of macrophages to bind the ligand [27]. The results of our study indicate that IFN- $\gamma$ may reduce the binding function of nonopsonic receptors and then interfere with the phagocytosis of monocytes and macrophages. In the innate immune response, IFN- $\gamma$ enhanced killing of opsonized pathogens, antigen presentation, and production of inflammatory mediators. In the other side, IFN- $\gamma$ diminished phagocytosis of nonopsonized particles, included bacteria and sheep red blood cells. Both opsonized and nonopsonized phagocytosis were important which were worthy to be further investigated. The mechanism involved in opsonized phagocytosis would be considered as the research fields of our future study.

To confirm whether the decreased PP caused by IFN- $\gamma$ is accompanied by changes in production performance, egg production traits were investigated. The data indicate that the laying rate remarkably improved at 2 and 3 wk following IFN- $\gamma$ administration, at a time when the PP was inhibited. This result agreed with that in our previous study, in which chickens with low PP had a higher laying rate in the early period. Furthermore, it was reported that Taiwan country chicken with lower $\gamma$-globulin concentrations showed subdued carbon clearance to the supernatant fraction of ink and higher egg production during the period from 16 to 52 wk of age [28]. 
The reproductive endocrinology of chickens is closely linked with their production performance [29]. Previous research has confirmed that FSH promotes follicular development and maturation and ultimately affects egg production [30-34]. In line with the laying rate results, chickens in the treatment group had higher FSH levels at $14 \mathrm{~d}$ post-infection and higher IFN- $\gamma$ levels at 14 and $21 \mathrm{~d}$ post-infection, at a time when monocyte and macrophage phagocytosis was at its lower value. Furthermore, the FSH level increased two times at 1 and 3 $\mathrm{d}$ with a rapid decrease in phagocytosis caused by IFN- $\gamma$. Thus, chicken IFN- $\gamma$ caused a decrease in monocyte and macrophage phagocytosis and simultaneously improved FSH levels, leading to an increased laying rate. These findings indicated that IFN- $\gamma$ may have a direct or indirect influence on the synthesis or secretion of FSH.

The synthesis and release of FSH are regulated by the pituitary, which is the master gland and crucial bridge between the central nervous system and endocrine system [35-38]. FSH consists of a common alpha subunit noncovalently attached to a distinct beta subunit that determines the species specificity [39-41]. Studies have found that IFN- $\gamma$ might affect hormone secretion by the pituitary. In female Wistar rats, a significant increase in prolactin $(P R L)$ in anterior pituitary cells was observed after stimulation with IFN- $\gamma$ at concentrations of $0.1 \mathrm{ng} / \mathrm{mL}, 1 \mathrm{ng} / \mathrm{mL}$, and $10 \mathrm{ng} / \mathrm{mL}$ [42]. In this study, our data showed that IFN- $\gamma$ has a direct influence on FSH synthesis and secretion by the pituitary, providing an explanation for the increased FSH levels at 1, 3, 7, and $14 \mathrm{~d}$ after injection with IFN- $\gamma$. It was reported that the transcription of $G H$ in the dairy cow anterior pituitary was obviously improved after treatment with IFN- $\gamma$ for $24 \mathrm{~h}$ at $10 \mathrm{ng} / \mathrm{mL}, 20 \mathrm{ng} / \mathrm{mL}, 40 \mathrm{ng} / \mathrm{mL}$, and $80 \mathrm{ng} / \mathrm{mL}$ [43]. In addition, treatment with IFN- $\gamma$ at $10^{2}$ and $10^{3} \mathrm{U} / \mathrm{mL}$ resulted in increased activity of $h G H$ in rat pituitary tumor cells [19]. Therefore, the significant up-regulation of the $F S H-\beta$ transcriptional level in the pituitary induced more secretion of FSH, which suggests that the IFN- $\gamma$ has the ability to regulate pituitary function in dwarf chickens.

IFN- $\gamma$ performs regulatory functions through combination with a specific hormone-receptor complex on the surface of cells formed by IFNGR1 (IFN- $\gamma$ receptor $\alpha$ chain) and IFNGR2 (IFN- $\gamma$ receptor $\beta$-chain). IFNGR1 and IFNGR2 are mutually interdependent in their functions $[8,44-46]$. Impaired IFN- $\gamma$-induced signaling and reduced IFN- $\gamma$ activity were observed in IFNGR1- or IFNGR2- deficient mouse embryonic fibroblasts [9]. In the current study, increased mRNA expression levels of IFNGR1 and IFNGR2 were observed in the pituitary following treatment with IFN- $\gamma$. The IFN- $\gamma$ ligand is a dimmer and binds to a heterodimer receptor, which activates the signal transduction cascades and results in the dimerization of the signal transducers and activators of gene transcription $[7,8,47]$. In our research, the combination of endogenous IFN- $\gamma$ ligand and the preassembled up-regulated receptor complex activated the relevant signaling pathways and led to increased $F S H-\beta$ expression at the transcription level, promoting the synthesis and secretion of FSH.

Collectively, IFN- $\gamma$ has an effect on monocyte and macrophage PP and the secretion of pituitary hormones. We found that IFN- $\gamma$ suppressed monocyte and macrophage phagocytosis and improved the production performance in dwarf chickens. In future breeding programs, IFN $-\gamma$ may be considered as a regulator to maintain the dynamic balance between the immune effect and production traits.

\section{Conclusions}

IFN- $\gamma$ inhibited monocyte and macrophage phagocytosis; enhanced the secretion of FSH via up-regulating the expression of IFNGR1, IFNGR2, and FSH- $\beta$; and accordingly improved the laying rate. This study can provide a practical and theoretical basis for the links between the immune effect and production performance, and it offers a novel approach for selective breeding.

\section{Abbreviations \\ FSH: Follicle-stimulating hormone; FSH- $\beta$ : Follicle stimulating hormone beta subunit; GAPDH: Glyceraldehyde-3-phosphate dehydrogenase; \\ IFNGR1: Interferon gamma receptor 1; IFNGR2: Interferon gamma receptor 2; IFN- $\gamma$ : Interferon- $\gamma ;$ MTT: Thiazolyl blue tetrazolium bromide; \\ PBMCs: Peripheral blood mononuclear cells; PBS: Phosphate buffered saline; PP: Phagocytosis product}

\section{Acknowledgements}

The authors gratefully thank all of the staff at the Genetic Resource Center of China Agricultural University (Beijing, China) for taking care of the animals.

\section{Funding}

This work was supported by grants from National Natural Science Foundation of China (3157130570), Young Scientist Supporting Project, Program for Changjiang Scholars and Innovative Research Team in University (IRT_15R62), Farm Animals Germplasm Resource Platform, National Transgenic Creature Breeding Grand Project (2016ZX08008-003), Innovation Base Cultivation and Development Project-research on precise genetic modify in sheep (Z171100002217072).

\section{Availability of data and materials}

The data analyzed during the current study are available from the corresponding author on reasonable request.

\section{Authors' contributions}

$Z L, L L$, and $Y Y$ designed the study. $Y Y, S L$, and $Y Z$ participated in sample collection. YY performed all experiments, analyzed the data, and drafted the manuscript. $Y Y$ and $L L$ revised the manuscript. All authors read and approved the final manuscript.

\section{Ethics approval}

All animal procedures were approved by the Experimental Animal Care and Use Committee at China Agricultural University (Beijing, China). The experiments were performed according to the regulations and guidelines established by this committee.

Competing interests

The authors declare that they have no competing interests. 


\section{Author details}

Key Laboratory of Animal Genetics and Breeding of the Ministry of Agriculture, Beijing Key Laboratory for Animal Genetic Improvement, Department of Animal Genetics and Breeding, College of Animal Science and Technology, China Agricultural University, Beijing 100193, China. ${ }^{2}$ Department of Animal Genetics and Breeding, College of Animal Science and Technology, China Agricultural University, Beijing 100193, China.

\section{Received: 20 October 2017 Accepted: 19 April 2018}

Published online: 23 May 2018

\section{References}

1. Kulkarni G, Zhang H. Evaluation of reproductive characteristics of 21 highly inbred lines of white leghorns divergently selected for or segregating in tumor resistance. Open J Animal Sci. 2015;5:59-70.

2. Blendea A, Cazimir I, Cornila N, Irimescu I, Damian A. Anatomohistological study regarding the ovary and oviduct in different age groups in the chicken (Gallus domesticus). Sci Works C Series V. 2012:58:21-30.

3. Zhao XL, Honaker CF, Siegel PB. Phenotypic responses of chickens to long-term selection for high or low antibody titers to sheep red blood cells. Poult Sci. 2012;91:1047-56

4. Rauw WM, Kanis E, Noordhuizen-Stassen EN, Grommers FJ. Undesirable side effects of selection for high production efficiency in farm animals: a review. Livest Prod Sci. 1998:56:15-33.

5. van der Most PJ, de Jong B, Parmentier HK, Verhulst S. Trade-off between growth and immune function: a meta-analysis of selection experiments. Funct Ecol. 2011;25:74-80.

6. Mangel M, Stamps J. Trade-offs between growth and mortality and the maintenance of individual variation in growth. Evol Ecol Res. 2001;3:583-93.

7. Pestka S, Krause CD, Walter MR. Interferons, interferon-like cytokines, and their receptors. Immunol Rev. 2004;202:8-32.

8. Goossens KE, Ward AC, Lowenthal JW, Bean AGD. Chicken interferons, their receptors and interferon-stimulated genes. Dev Comp Immunol. 2013;41:370-6.

9. Schroder K, Hertzog PJ, Ravasi T, Hume DA. Interferon-y: an overview of signals, mechanisms and functions. J Leukoc Biol. 2004;75:163-89.

10. Vankelecom H, Carmeliet $P$, Heremans H, Van Damme J, Dijkmans R, Billiau A, et al. Interferon-gamma inhibits stimulated adrenocorticotropin, prolactin, and growth-hormone secretion in normal rat anterior-pituitary cell-cultures. Endocrinology. 1990;126:2919-26

11. Fratti RA, Ghannoum MA, Edwards JE Jr, Filler SG. Gamma interferon protects endothelial cells from damage by Candida albicans by inhibiting endothelial cell phagocytosis. Infect Immun. 1996;64:4714-8.

12. Yong SB, Song Y, Kim HJ, Ain QU, Kim YH. Mononuclear phagocytes as a target, not a barrier, for drug delivery. J Control Release. 2017;259:53-61.

13. Djaldetti M, Salman H, Bergman M, Djaldetti R, Bessler H. Phagocytosis-the mighty weapon of the silent warriors. Microsc Res Tech. 2002;57:421-31.

14. Sun K, Metzger DW. Inhibition of pulmonary antibacterial defense by interferon- $\gamma$ during recovery from influenza infection. Nat Med. 2008; 14:558-64.

15. Arimori Y, Nakamura R, Yamada H, Shibata K, Maeda N, Kase T, et al. Type I interferon plays opposing roles in cytotoxicity and interferon- $\gamma$ production by natural killer and $C D 8^{+}$T cells after influenza a virus infection in mice. J Innate Immun. 2014:6:456-66.

16. Wang Z, Zhou S, Sun C, Lei T, Peng J, Li W, et al. Interferon-gamma inhibits nonopsonized phagocytosis of macrophages via an mTORC1-c/EBPbeta pathway. J Innate Immun. 2015;7:165-76.

17. Frausto-Del-Río D, Soto-Cruz I, Garay-Canales C, Ambriz X, Soldevila G, Carretero-Ortega J, et al. Interferon gamma induces actin polymerization, Rac1 activation and down regulates phagocytosis in human monocytic cells. Cytokine. 2012;57:158-68.

18. Capsoni F, Minonzio F, Ongari AM, Bonara P, Pinto G, Carbonelli V et al. Fc receptors expression and function in mononuclear phagocytes from AIDS patients: modulation by IFN-gamma. Scand J Immunol. 1994;39:45-50.

19. Gong FY, Deng JY, Shi YF. IFN-gamma increases the hGH gene promoter activity in rat GH3 cells. Horm Res. 2003:60:14-20.

20. Späth-Schwalbe E, Porzsolt F, Digel W, Born J, Kloss B, Fehm HL. Elevated plasma cortisol levels during interferon-gamma treatment. Immunopharmacology. 1989;17:141-5.
21. Li H, Zhang Y, Ning ZH, Deng XM, Lian ZX, Li N. Effect of selection for phagocytosis in dwarf chickens on immune and reproductive characters. Poult Sci. 2008;87:41-9.

22. Sun SF, Pan QZ, Hui X, Zhang BL, Wu HM, Li H, et al. Stronger in vitro phagocytosis by monocytes-macrophages is indicative of greater pathogen clearance and antibody levels in vivo. Poult Sci. 2008;87: 1725-33.

23. Ma H, Ning ZH, Lu Y, Han HB, Wang SH, Mu JF, et al. Monocytesmacrophages phagocytosis as a potential marker for disease resistance in generation 1 of dwarf chickens. Poult Sci. 2010;89(9):2022.

24. Ma H, Lian ZX, Liu WB, Han HB, Yuan YT, Ning ZH. Salmonella Pullorum resistance in dwarf chickens selected for high macrophage phagocytosis. J Appl Poult Res. 2017:26:437-48.

25. Schmittgen TD, Livak KJ. Analyzing real-time PCR data by the comparative $C_{T}$ method. Nat Protoc. 2008:3:1101-8.

26. Rüegg SJ, Jungi TW. Antibody-mediated erythrolysis and erythrophagocytosis by human monocytes, macrophages and activated macrophages. Evidence for distinction between involvement of high-affinity and low-affinity receptors for lgG by using different erythroid target cells. Immunology. 1988:63:513-20.

27. Speert DP, Thorson L. Suppression by human recombinant gamma interferon of in vitro macrophage nonopsonic and opsonic phagocytosis and killing. Infect Immun. 1991;59:1893-8.

28. Chao CH, Lee YP. Relationship between reproductive performance and immunity in Taiwan country chickens. Poult Sci. 2001;80:535-40.

29. Long L, Wu SG, Yuan F, Zhang HJ, Wang J, Qi GH. Effects of dietary octacosanol supplementation on laying performance, egg quality, serum hormone levels, and expression of genes related to the reproductive axis in laying hens. Poult Sci. 2017;96:894-903.

30. Li Z, Johnson AL. Regulation of P450 cholesterol side-chain cleavage messenger ribonucleic acid expression and progesterone production in hen granulosa cells. Biol Reprod. 1993:49:463-9.

31. Christians JK, Williams TD. Effects of porcine follicle-stimulating hormone on the reproductive performance of female zebra finches (Taeniopygia guttata). Gen Comp Endocrinol. 2002;125:121-31.

32. Nataraja SG, Yu HN, Palmer SS. Discovery and development of smal molecule allosteric modulators of glycoprotein hormone receptors. Front Endocrinol (Lausanne). 2015;6:142.

33. Johnson AL, Lee J. Granulosa cell responsiveness to follicle stimulating hormone during early growth of hen ovarian follicles. Poult Sci. 2016:95:108-14.

34. Yamamoto Y, Adam Luckenbach J, Goetz FW, Young G, Swanson P. Disruption of the salmon reproductive endocrine axis through prolonged nutritional stress: changes in circulating hormone levels and transcripts for ovarian genes involved in steroidogenesis and apoptosis. Gen Comp Endocrinol. 2011:172:331-43.

35. Yamamura N, Takeishi M, Goto H, Tagami M, Mizutani T, Miyamoto K, et al. Expression of messenger RNA for gonadotropin receptor in the granulosa layer during the ovulatory cycle of hens. Comp Biochem Physiol A Mol Integr Physiol. 2001;129:327-37.

36. Uhm SJ, Gupta MK, Yang JH, Chung HJ, Min TS, Lee HT. Epidermal growth factor can be used in lieu of follicle-stimulating hormone for nuclear maturation of porcine oocytes in vitro. Theriogenology. 2010;73:1024-36.

37. Lin JX, Jia YD, Zhang CQ. Effect of epidermal growth factor on folliclestimulating hormone-induced proliferation of granulosa cells from chicken prehierarchical follicles. J Zhejiang Univ Sci B. 2011;12:875-83.

38. Yoshimura $Y$, Okamoto T, Tamura T. Effects of luteinizing-hormone and follicle-stimulating-hormone on the progesterone-receptor induction in chicken granulosa cells in vivo. Poult Sci. 1995;74:147-51.

39. Grzegorzewska AK, Sechman A, Paczoska-Eliasiewicz HE, Rzasa J. The expression of pituitary FSHbeta and LHbeta mRNA and gonadal FSH and LH receptor mRNA in the chicken embryo. Reprod Biol. 2009;9:253-69.

40. Krishnan KA, Proudman JA, Bahr JM. Purification and characterization of chicken follicle-stimulating hormone. Comp Biochem Physiol B. 1992;102:67-75.

41. Shen ST, Yu JY. Cloning and gene expression of a cDNA for the chicken follicle-stimulating hormone (FSH)-beta-subunit. Gen Comp Endocrinol. 2002;125:375-86.

42. Yamaguchi $M$, Koike $K$, Matsuzaki N, Yoshimoto $Y$, Taniguchi T, Miyake $A$, et al. The interferon family stimulates the secretions of prolactin and interleukin- 6 by the pituitary-gland in vitro. J Endocrinol Investig. 1991;14:457-61. 
43. Wang JF, Fu SP, Li SN, Yang ZQ, Xue WJ, Li ZQ, et al. Establishment and characterization of dairy cow growth hormone secreting anterior pituitary cell model. In Vitro Cell Dev Biol Anim. 2014;50:103-10.

44. Han X, Chen T, Wang M. Molecular cloning and characterization of chicken interferon-gamma receptor al pha-chain. J Interf Cytokine Res. 2008;28:445-54.

45. Bach EA, Aguet M, Schreiber RD. The IFN gamma receptor: a paradigm for cytokine receptor signaling. Annu Rev Immunol. 1997;15:563-91.

46. Han $C L$, Zhang W, Dong HT, Han X, Wang M. A novel gene of beta chain of the IFN-gamma receptor of Huiyang chicken: cloning, distribution, and CD assay. J Interf Cytokine Res. 2006;26:441-8.

47. Lasfar A, Cook JR, Cohen Solal KA, Reuhl K, Kotenko SV, Langer JA, et al. Critical role of the endogenous interferon ligand-receptors in type I and type II interferons response. Immunology. 2014;142:442-52.

Ready to submit your research? Choose BMC and benefit from:

- fast, convenient online submission

- thorough peer review by experienced researchers in your field

- rapid publication on acceptance

- support for research data, including large and complex data types

- gold Open Access which fosters wider collaboration and increased citations

- maximum visibility for your research: over $100 \mathrm{M}$ website views per year

At BMC, research is always in progress.

Learn more biomedcentral.com/submissions 